\title{
Assessing the Operational Carbon at University ${ }^{\dagger}$
}

\author{
Irina Safitri Zen 1,*, Masilah Bandi ${ }^{2}$, Kasturi Devi Karniah ${ }^{1}$, Iklil Nabihah Binti Abu Bakar' ${ }^{1}$ and \\ Rozana Zakaria ${ }^{3}$ \\ 1 Faculty of Built Environment \& Surveying, Universiti Teknologi Malaysia, Skudai 81310, Malaysia; \\ kasturi@utm.my (K.D.K.); iklilnabihah@gmail.com (I.N.B.A.B.) \\ 2 Malaysia Green Technology Corporation, Persiaran Usahawan, Jalan 9/10, Seksyen 2, 43650 Bandar Baru \\ Bangi, Selangor, Malaysia; masilah@greentechmalaysia.my \\ 3 Faculty of Engineering, Universiti Teknologi Malaysia, Skudai 81310, Malaysia; rozana@utm.my \\ * Correspondence: irinasafitri@utm.my; Tel.: +60-7558-4286 \\ + Presented at the Economy, Sustainable Development and Energy International Conference (ESDEIC), \\ Edinburgh, Scotland, UK, 25-27 June 2018.
}

Published: 1 November 2018

\begin{abstract}
The establishment of low carbon assessment initiatives is a crucial task especially at the city level. The determination of which source of carbon contributed more require robust data set and strategic approach. Hence, by using the campus as a small city approach, the establishment of carbon assessment and its' reduction initiatives was required to keep track of the hotspot of the carbon source. The substantial amount of carbon source from campus operations such as energy consumption in the building, waste generation, and water consumption were identified. Moreover, as institutions of higher education, the execution of low carbon campus was initiated structurally involves the triangulation of research activities, teaching \& learning and as well as campus operations or known as campus living lab approach. The application of low carbon cities framework, LCCF and assessment system enables to strategize the low carbon campus initiatives through the use of carbon footprint concept and the LCCF carbon track.
\end{abstract}

Keywords: carbon; energy; campus; sustainability; city, low carbon

\section{Introduction}

Pursuing the carbon assessment projects at University level is crucial to quantify and justify the environmental impact of their activities on the global climate change challenges. University is a synonym with a small city. The livelihood inside campus consists of hostels and houses with its basic amenities such as clinics, restaurant, and cafeteria, sports facilities, parks, transportation networks and infrastructures such as street lighting, pedestrian walkway and cycling facilities to serve the campus community. It is where the campus operation generates carbon from energy used in buildings for cooling, lighting and other electrical appliances. Waste generated from café and water consumption are among the infrastructure congregate in a closed loop type of campus in high density population. Hence, it is mimic city characters and environment which its' added more to carbon emissions intensity [1]. Moreover, the UTM Campus Sustainability involvement in the nationwide of low carbon cities framework, LCCF, and assessment system [2] provide various opportunities to explore the strategic low carbon initiative and accelerate the process. While, challenges faced by local authority in obtaining data at the city level provide platform for collaboration where IHE function as a testbed or living laboratories [3-5] for the assessment tools and demonstrates the co-creation sustainability [6] in Malaysia which also function as agent of changes to wider society [7-9] to contribute to the country's voluntary commitment of $40 \%$ carbon emission reduction by 2030 [10]. 


\section{Literature Review}

The Low Carbon Cities Framework and Assessment System (LCCF) is a city scale of carbon emission assessment for the local authorities. It was developed by the Malaysia Green Technology Corporation or MalaysiaGreenTech, Ministry of Energy, Green Technology and Water of Malaysia [5] as one of the initiatives to translate the Malaysia National Green Technology Policy at the township level [10]. The policy stated that 'Green Technology shall be a driver to accelerate the national economy and promote sustainable development'.

Carbon footprint, CF assessment for the institution of higher education helps in identifying which sectors contributing more to strategize carbon emissions reductions effort. The concept of LCCF which has based on the CF and rooted in the ecological footprint, it is where the carbon emitted resulted from various activities was calculated. For example, the carbon emissions estimation and hotspots in operating the university [11]. Priority given for operational carbon is due to high amount of carbon emitted from campus operation, such as energy and waste [11-13].

\section{Materials \& Method}

In general, the LCCF framework and assessment system consist of four component of performances criteria; Urban Environment, Urban Transportation, Urban Infrastructures and Building [2]. The data compute and processed into the LCCF Track online system (http://lccftrack.greentownship.my/admin/users/login) to get the level of the Best Practices of the LCCF Diamond Rating System. Beside high carbon emission comes from campus operation, sources of carbon also based on the consistency of data availability. The establishment of the UTM LCCF method covers four stages, (i) Recognize the Key Partners \& Stakeholders, (ii) Establish the baseline data (data identification and availability) and boundary, (iii) Develop Campus Strategy (Define Objectives and Set the Target), and iv. implementation and review of the UTM LCCF Boundary.

The UTM population data provided by the Academic Office recorded approximately 26,038 for the year 2013, 25,825 for the year 2014 and 28,306 for the year 2015. The physical characteristic of UTM covers an 1145 ha of land and a total of 805 buildings consisting of 14 faculties, 13 hostels and 6 administration buildings that total up to the 851.43 ha GFA (gross floor area). Hence, it used as the total area of UTM LCCF assessment which is where the waste produces, energy consumption and water used was recorded. Based on data available for the same years, the baseline data established covers waste generation, monthly energy consumption record in kilowatt hour, $\mathrm{kWh}$ and water usage for the year 2013. The details data from the three sectors are as follow:

- Water Sector. Fluctuation in water usage recorded by 3,360,483.00 $\mathrm{m}^{3}(2013), 3,650,412.00 \mathrm{~m}^{3}$ (2014) and 3,458,066.00 $\mathrm{m}^{3}$ (2015). Effort establishes to reduce the non-revenue water, NRW due to pipe breaking. The per capita water usage recorded $129.06 \mathrm{~m}^{3}$ (2013), $141.35 \mathrm{~m}^{3}$ (2014) and $122.17 \mathrm{~m}^{3}$ (2015).

- Energy Sector. Data for on-site fossil fuel consumption and grid electricity in the entire gross internal area of UTM-owned buildings is collected from the operation department and UTM SEMP [8]. Further, the energy consumption recorded at 5,724,821 kWh $(2013,57,198,958 \mathrm{kWh}$ (2014) and 57,546,794 kWh (2015). Further, the energy usage per capita recorded $2198.40 \mathrm{kWh}$ (2013), 2214.87 kWh (2014) and 2033.02 kWh (2015).

- Waste Sector. Waste generation recorded generated about $708.70 \mathrm{tCO}^{2} /$ year emitted in the year 2013 and reduce to $581.93 \mathrm{tCO}^{2} /$ year in the year 2015. There is $126.77 \mathrm{tCO}^{2} /$ year of carbon emission decrease that brings reduction about $17.89 \%$ and supported by low carbon emissions activities $[4,5]$.

\section{Results \& Discussion}

The UTM LCCF Track produces the total carbon emissions from the three sectors are energy, water and waste approximately $3573.51 \mathrm{tCO}^{2} /$ year (Table 1). It is based on the total carbon emitted 45,564.96 tCO2/year (2013) compared to $41,991.46 \mathrm{CO}^{2} /$ year (2015). The reduction is about $7.84 \%$ which is classified as Best Practice (BP) 1 or equal to one diamond of the LCCF Diamond Rating 
System [2]. Several studies recorded a similar result which is the energy consumption and waste generation [12,13]. The two, then become the focus for carbon emissions reduction which involves triangulation of research, teaching \& learning and campus operation. It is familiar as a campus living lab $[3,4,7]$, for a testbed of robust scientific development and greening the curriculum as well as educate the students in a real-world setting $[6,7,11,13,14]$ The 25 UK IHE initiative stimulate the sustainability initiatives to the city [9] and the co-creation for sustainability [6]. Several cities involve in low carbon initiatives by finding the alternatives scenario such as in Beijing, China [15] and observes the low carbon development pattern in several typical cities in China [16]. It is important to keep track the low carbon development for future cities development [17].

Table 1. UTM LCCF Result.

\begin{tabular}{|c|c|c|c|c|c|c|}
\hline \multicolumn{7}{|c|}{ LOW CARBON FINAL ASSESSMENT RESULT } \\
\hline \multirow{3}{*}{$\begin{array}{l}\text { Calculator } \\
\text { Criteria }\end{array}$} & \multirow[t]{3}{*}{ Element } & \multicolumn{2}{|c|}{$\begin{array}{l}\text { TOTAL CARBON } \\
\text { EMISSIONS }\end{array}$} & \multirow{2}{*}{\multicolumn{2}{|c|}{$\begin{array}{c}\text { Reduction } \\
\text { Achieved } \\
\text { (B-P) }\end{array}$}} & \multirow{3}{*}{ Remarks } \\
\hline & & 2013 & 2015 & & & \\
\hline & & $\mathrm{tCO}_{2} /$ Year & $\mathrm{tCO}_{2} /$ Year & $\mathrm{tCO}_{2} /$ Year & $\%$ & \\
\hline \multirow{2}{*}{ LANDUSE } & $\begin{array}{c}\text { Carbon Storage in Soil } \\
\text { (losses) }\end{array}$ & 50.28 & 50.28 & 0.00 & 0.00 & \\
\hline & $\begin{array}{l}\text { Carbon Sequestration } \\
\text { by Vegetation (losses) }\end{array}$ & 0.00 & 0.00 & 0.00 & 0.00 & \\
\hline \multirow{3}{*}{$\begin{array}{l}\text { OPERATIONAL } \\
\text { CARBON }\end{array}$} & Energy & $46,484.15$ & $42,987.46$ & 3496.70 & 7.52 & $\begin{array}{c}\text { Carbon } \\
\text { decreased }\end{array}$ \\
\hline & Water & 1530.69 & 1580.65 & -49.96 & -3.26 & $\begin{array}{c}\text { Carbon } \\
\text { increased }\end{array}$ \\
\hline & Waste & 708.70 & 581.93 & 126.77 & 17.89 & $\begin{array}{c}\text { Carbon } \\
\text { decreased }\end{array}$ \\
\hline TOTA & EMISSIONS & $45,564.96$ & $41,991.46$ & 3573.51 & 7.84 & $\mathrm{BP} 1$ \\
\hline
\end{tabular}

Overall, waste sector records the highest percentage of carbon emission reductions up to $17.89 \%$ compared to the energy sector with a record reduction up to $7.52 \%$. Whilst, an increasing water consumption implicates an increase in carbon emission up to $3.26 \%$. The old piping system caused a high non-revenue water (NRW). However, several technical solutions approaches have been taking place. Several low carbon campus initiatives for the energy sector in place under the UTM Sustainable Energy Management Program, as a combination of the technical solutions, managerial and behavioral awareness campaign [8]. The waste sector carbon emissions reduction was executed under the establishment of the Green office and Green Food Court. The effort involves students where campus used as their learning site and supported by related research $[3,4,8]$.

\section{Conclusions}

The study reveals that a substantial amount of carbon from energy consumption in building contributing more but waste reductions initiative gives more percentage of overall carbon emissions reduction. IHE has the potential to be the change agent for the society in leading the carbon reduction initiatives and fulfill the fourth mission of IHE in co-creation sustainability. It is also a method to monitor their carbon emissions from the various campus activities is also part of the climate adaptation and mitigations initiative. As a lead role, IHE plays crucial functions to facilitate local authority on the application and benefits of the carbon assessment projects by improving the data management system. students' involvements in low carbon campus initiatives provide a real-world experience as part of the social learning process. 
Supplementary Materials: The following are available online at http://ccftrack.greentownship.my/admin/ users/login.

Author Contributions: I.S.Z. conceived and designed the experiments, M.B. focus on energy data, K.D.K. analysed the land use data, R.Z. analyzed the water data and I.N.B.A.B. computed the data into LCCF Track system. All of us involves in the interaction with MalaysiaGreenTech team.

Funding: This research received external funded by the MalaysiaGreenTech, Ministry of Energy, Green Technology and Water, Malaysia (Vot No. 4B113) and the Ministry of Higher Education, Malaysia for the campus living lab grant (Vot. No. 00M88).

\section{Reference}

1. Chavez, A.; Ramaswami, A. Progress toward low carbon cities: Approaches for transboundary GHG emissions' footprinting. Carbon Manag. 2011, 2, 471-482.

2. Kementerian Tenaga, Teknologi Hijau dan Air (KeTTHA). Low Carbon Cities Framework E Assessment System; KeTTHA: Kuala Lumpur, Malaysia, 2011; ISBN 978-967-5893-06-3.

3. Zen, I.S. Exploring Living Learning Laboratory: An Approach to Strengthen Campus Sustainability Initiatives by Using Sustainability Science Approach. Int. J. Sustain. High. Educ. 2017, 1, 1-15.

4. Zen, I.S.; Subramaniam, D.; Sulaiman, H.; Saleh, A.L.; Omar, W.; Salim, M.R. Institutionalize Waste Minimization Governance Towards Campus Sustainability: A Case Study of Green Office Initiatives in Universiti Teknologi Malaysia. J. Clean. Prod. 2016, 135, 1407-1422.

5. Zen, I.S. University Campus as a Living Lab to Combat Climate Change Challenge. In Rising to the Challenge Malaysia's Contribution to the SDGs; Mazlin, M., Lee, K.E., Subarna, S., Eds.; Penerbit Universiti Kebangsaan Malaysia (UKM Press): Bangi, Malaysia, 2017; 234p.

6. Trencher, G.; Yarime, M.; McCormick, K.B.; Doll, C.N.; Kraines, S.B. Beyond the third mission: Exploring the emerging university function of co-creation for sustainability. Sci. Public Policy 2013, 41, 151-179.

7. Evans, J.; Jones, R.; Karvonen, A.; Millard, L.; Wendler, J. Living labs and co-production: University campuses as platforms for sustainability science. Curr. Opin. Environ. Sustain. 2015, 16, 1-6.

8. Zen, I.S.; Masilah, B.; Rozana, Z.; Abdul Latif, S. The UTM Sustainable Campus: Institutionalize Sustainability, the Living Lab Approach, and Sustainable Energy Management Program. In Proceedings of the UI Green Metrics Workshop, Jakarta, Indonesia, 21 November 2013; pp. 53-60.

9. Devlin, M. Futures Forum 1999: Exploring the Future of Higher Education (Fall 1998). Available online: https://eric.ed.gov/?id=ED435329 (accessed on 7 June 2018).

10. Kementerian Tenaga Teknologi Hijau \& Air. The National Green Technology Policy; Kementerian Tenaga Teknologi Hijau \& Air: Kuala Lumpur, Malaysia, 2009.

11. Larsen, H.N.; Pettersen, J.; Solli, C.; Hertwich, E.G. Investigating the Carbon Footprint of a UniversityThe case of NTNU. J. Clean. Prod. 2013, 48, 39-47.

12. Sorrell, S. Barriers to Energy Efficiency in the UK Higher Education Sector; DG Research under the JOULE Project 'Barriers to Energy Efficiency in Public and Private Organizations'; SPRU: London, UK, 2000.

13. Roy, R.; Potter, S.; Yarrow, K. Designing low carbon higher education systems. Int. J. Sustain. High. Educ. 2008, 9, 116-130.

14. Abubakar, I.R.; Al-Shihri, F.S.; Ahmed, S.M. Students' Assessment of Campus Sustainability at the University of Dammam, Saudi Arabia. Sustainability 2016, 8, 59. doi:10.3390/su8010059.

15. Zhang, L.; Feng, Y.; Chen, B. Alternative Scenarios for the Development of a Low-Carbon City: A Case Study of Beijing, China. Energies 2011, 4, 2295-2310. doi:10.3390/en4122295.

16. Su, M.; Liang, C.; Chen, B.; Chen, S.; Yang, Z. Low-Carbon Development Patterns: Observations of Typical Chinese Cities. Energies 2012, 5, 291-304. doi:10.3390/en5020291.

17. Dienst, C.; Schneider, C.; Xia, C.; Saurat, M.; Fischer, T.; Vallentin, D. On Track to Become a Low Carbon Future City? First Findings of the Integrated Status Quo and Trends Assessment of the Pilot City of Wuxi in China. Sustainability 2013, 5, 3224-3243. doi:10.3390/su5083224. 